\section{Analcime-bearing rocks as advanced sorbents}

DMITRY A. SHUSHKOV - Institute of Geology, FRC Komi Science Center, Ural Branch of the Russian Academy of Sciences, Russian Federation - dashushkov@geo.komisc.ru

OLGA B. KOTOVA - Institute of Geology, FRC Komi Science Center,

Ural Branch of the Russian Academy of Sciences, Russian Federation • kotova@geo.komisc.ru

JAmAL-ELDIn F. M. IBRAHIM - Institute of Ceramics and Polymer Engineering, University of Miskolc, Hungary • jamalfadoul@gmail.com

MARIA HARJA - Gheorghe Asachi Technical University of lași,

Faculty of Chemical Engineering and Environmental Protection, laşi, Romania - maria_harja06@yahoo.com

LÁszLó A. GÖMZE - Institute of Ceramics and Polymer Engineering,

University of Miskolc, Hungary - femgomze@uni-miskolc.hu

TATYANA N. SHCHEMELININA - Institute of Biology, FRC Komi Science Center,

Ural Branch of the Russian Academy of Sciences, Russian Federation • tatyanakomi@mail.ru

GRIGoRIY V. IGNATIEV • Institute of Geology, FRC Komi Science Center,

Ural Branch of the Russian Academy of Sciences, Russian Federation • ignatiev.grigoriy@gmail.com

Érkezett: 2020. 06. 30. - Received: 30. 60. 2020. - https://doi.org/10.14382/epitoanyag-jsbcm.2020.26

\section{Abstract}

The rational use of water and soil resources and their effective purification are actual scientific problems for modern society. Inexpensive and effective natural sorbents, zeolites, are widely used to solve environmental problems and improve the safety of the use of water and soil resources. This article presents results of our study of the sorption properties of analcime-bearing rocks in the north-east of the European part of Russia. Experiments and analytical studies were carried out using modern analytical equipment. The high sorption activity of these rocks with respect to radioactive elements (uranium, radium, thorium) was established. The simulated biogeosorbents based on analcime-bearing rocks and target microorganisms exhibited high sorption and destructive properties to oil products and phenols, ensured preservation and increased the growth of Chlorella vulgaris microalgae cells under stress conditions: with increased salinity and exposure to organic pollutants.

Keywords: analcime-bearing rocks, zeolites, sorbents, biogeosorbents, radionuclides, phenol Kulcsszavak: analcimet hordozó kôzetek, zeolitok, szorbensek, biogeoszorbensek, radionuklidok, fenol

\section{Introduction}

Zeolites are microporous framework aluminosilicates with high sorption and ion exchange capacities. They have sufficient mechanical strength, thermal, chemical and radiation resistance; contain non-toxic exchange cations $(\mathrm{Na}, \mathrm{K}, \mathrm{Ca}, \mathrm{Mg})$. Their physical and chemical properties largely depend on the type of zeolite and, accordingly, the features of its structure: channel and pore size, cavity volume, $\mathrm{Si} / \mathrm{Al}$ ratio, composition and position of cations. The main applications of zeolites in industry are catalysis, gas separation, and ion exchange [1-7]. The advantages of natural zeolites over synthetic analogues are their low price, a wide occurrence in the world, availability for mining. Compared to activated carbon, which is widely used in sorption processes, zeolites are characterized by lower regeneration costs $[8,9]$.

Currently, more than 90 types of natural zeolites are known $[10,11]$. Industrial clusters form clinoptilolite, mordenite, phillipsite, chabazite, stilbite, laumontite and analcime [3]. Analcime belongs to narrow-porous zeolites with a channel size $0.16 \times 0.42 \mathrm{~nm}[12,13]$.

In sedimentary rocks, analcime is associated with clay minerals, which are characterized by high sorption properties. Therefore, such rocks can be considered as sorption raw materials of mixed composition. Earlier studies of analcime-
Dmitry A. SHUSHKOV

Researcher of Laboratory of Technology of Mineral Raw, Institute of Geology, FRC Kom

Science Center, Ural Branch of the Russian Academy of Sciences. Author and co-author of 2 patents and more than 40 scientific articles. Russian Mineralogical Society.

Olga В. KOTOVA

is professor and Head of Laboratory of Technology of Mineral Raw, Institute of Geology. FRC Komi Science Center, Ural Branch of the Russian Academy of Sciences. Author and co-author of 4 patents and more than 150 scientific articles.Vice-president of Internationa Commission on Applied Mineralogy (IMA-ICAM)

Member of Russian Mineralogical Society.

Jamal Eldin F. M. IBRAHIM is a lecturer in the University of Bahri, Khartoum, Sudan, he graduated from University of Marmara Istanbul, Turkey, Institute of Pure and Applied Sciences, Department of Metallurgical and Materials Engineering, for the time being, he is a $\mathrm{PhD}$ student in the University of Miskolc, Institute of Polymer and Ceramics Engineering, under supervision of Prof. L. A. Gömze.

Maria HARJA

Is an associate professor in Department of Chemical Engineering at "Gheorghe Asachi" Technical University of lasi, Romania.She is author or co-author of over 160 scientific papers (59 ISI) and 17 books.

László A. GÖMZE

is establisher and professor of the Department of Ceramics and Silicate Engineering in the University of Miskolc, Hungary. He is author or co-author of 2 patents, 6 books and more than 300 scientific papers.

Tatyana N. SHCHEMELININA is a researcher and head of research group at the Institute of Biology, FRC Komi Science Center Ural Branch of the Russian Academy of Sciences. She is author or co-author of several scientific papers both in English and Russian languages.

Grigoriy V. IGNATIEV Junior researcher of Laboratory of Chemistry of Mineral Raw, Institute of Geology, Komi Science Center, Ural Branch of the Russian Academy of Sciences. He actually continues his studies as PhD student

bearing rocks have shown that they can be used in various fields of industry.

Some authors suggest using analcime as a raw material for aluminum [14-17]. The use of various kinds of influence ( $T$, hv, etc.) demonstrate the promise of using analcime-bearing rocks as raw materials for aluminum. So, in [18] experiments were conducted on the extractability of aluminum under acid exposure. It was shown that from 4.7 to $50.8 \% \mathrm{Al}_{2} \mathrm{O}_{3}$ passes into the solution. The highest recoverability of $\mathrm{Al}_{2} \mathrm{O}_{3}$ was achieved by exposure to $3 \% \mathrm{HCl}$ for 72 hours and $10 \% \mathrm{H}_{2} \mathrm{SO}_{4}$ for 24 and 120 hours. More than $30 \%$ was recovered by treatment with concentrated $\mathrm{HCl}$ for 48 hours and $5 \% \mathrm{HCl}$ for 24 and 120 hours. The quantity of $\mathrm{Al}_{2} \mathrm{O}_{3}$ in solution depends on the processing time, particle size, type of acid. $\mathrm{Al}_{2} \mathrm{O}_{3}$ concentrations have a complex pattern depending on these parameters. In [19-21], bauxites and aluminosilicates are considered as metal concentrators. 
Many works are devoted to the use of zeolites and clays as functional materials (ceramics, sorbents, etc.). Thus, a shortterm annealing of analcime-bearing rocks at temperatures $1050-1150{ }^{\circ} \mathrm{C}$ resulted in light porous materials with water absorption $3-7 \%$ and bulk density $260-280 \mathrm{~kg} / \mathrm{m}^{3}$, which can be used as heat-insulating materials. The authors [18] showed a technological scheme for producing ceramic material suitable for the production of facing tiles and some types of electrical ceramics. Other authors showed the increase in the strength characteristics and heat resistance by $20-25 \%$ of the epoxy composite material after introduction of analcime-bearing rocks from 0.5 to $25 \%$ (wt.) $[22,23]$. The data indicated suitability of the use of raw materials in crop production, animal breeding, soil-ecological and agrochemical fields.

This paper presents data on the sorption activity of analcimebearing rocks in relation to radionuclides (uranium, radium, thorium) and their ability to hold them; the efficiency of use in the treatment of drinking water and wastewater of enterprises is shown; sorption and destructive properties of analcimebearing rocks and biogeosorbents based on them in relation to oil products and phenols are estimated.

\section{Objects and methods of investigation}

\subsection{Objects}

The object of the study was the analcime-bearing rocks from several occurrences at the northeast of the European part of Russia: Veslyana (sample 551), Veslyanskoe - 1 (sample 56403), Eshmesskoe (sample 1/83), Chernorechenskoe (sample 58603).

\subsection{Methods}

The surface morphology and composition of samples were studied by TESCAN VEGA 3 LMH scanning electron microscope with X-Max energy dispersion attachment, Oxford Instruments, with an accelerating voltage $20 \mathrm{kV}$. Accelerating voltage $5 \mathrm{kV}$ was used to study microorganisms.

The chemical composition of the rocks was determined by silicate analysis for 12/14 components.

X-ray phase analysis was performed by Shimadzu XRD 6000 diffractometer (CuKa radiation, Ni filter, $30 \mathrm{kV}, 30 \mathrm{~mA}$ ). A powder sample was taken in the range $2-65^{\circ} 2 \theta$ with rate $1 \mathrm{deg} / \mathrm{min}$ and a scan step $2 \theta 0.05^{\circ}$. The phase composition of the clay fraction was determined by X-ray diffraction of oriented and non-oriented samples subjected to standard diagnostic treatments.

The specific surface area, the volume of micro- and mesopores, the total pore volume of the initial untreated powder sample were determined by the method of low-temperature physical sorption of nitrogen using a surface area and pore size analyzer NOVA 1200e, Quantachrome at a temperature of $-196^{\circ} \mathrm{C}$ with preliminary degassing at $350^{\circ} \mathrm{C}$ in vacuum within 2 hours.

The specific surface area of biogeosorbents (grain size 0.1 $0.25 \mathrm{~mm}$ ) was determined in two modes: without preliminary degassing and with degassing at $25{ }^{\circ} \mathrm{C}$ in vacuum for 2 hours. Degassing with heating above $25{ }^{\circ} \mathrm{C}$ was not carried out because the microorganisms were not able to survive. The specific surface area was calculated by BET method, the mesopore volume - by BJH method, the micropore volume by the Dubinin-Astakhov method.

\subsection{Experiments on the sorption of radionuclides}

Sorption was carried out under static conditions at room temperature and 1:10 solid to liquid ratio ( $3 \mathrm{~g}$ of sorbent and 30 $\mathrm{ml}$ of solution) from aqueous solutions of uranyl nitrate, radium chloride and thorium chloride, in which the radionuclides were represented by a natural mixture of isotopes. The initial concentration of radionuclides in the solution was: radium $0.32 \cdot 10^{-10} \mathrm{~g} / \mathrm{ml}$, uranium $-0.8 \cdot 10^{-6} \mathrm{~g} / \mathrm{ml}$, thorium $-0.5 \cdot 10^{-6} \mathrm{~g} /$ $\mathrm{ml}$. The concentrations of radionuclides in model solutions were higher than in natural water, which commonly contains between $\mathrm{n} \times 10^{-8}$ and $\mathrm{n} \times 10^{-5} \mathrm{~g} / \mathrm{L}$ uranium; thorium content is typically less than $\mathrm{n} \times 10^{-8} \mathrm{~g} / \mathrm{L}$, radium content ranges from $\mathrm{n} \times 10^{-14}$ to $\mathrm{n} \times 10^{-11} \mathrm{~g} / \mathrm{L}$ [24]. The contact time of the phases - 24 hours, $\mathrm{pH}$ of the solution -6 . The acidity of the liquid phase was adjusted to a certain level by alkalization with a concentrated (13 mol/L) ammonium hydroxide solution. $\mathrm{pH}$ of the liquid phase was measured by a compact $\mathrm{pH}$ meter "Wissenschaftlich-TechnischeWerkstatne GmbH", Germany.

The determination of natural radionuclides in the filtrates was carried out according to generally accepted methods. The uranium content was determined by the luminescent method (sensitivity $2.0 \cdot 10^{-8} \mathrm{~g} / \mathrm{g}$ ) by the luminescence of $\mathrm{NaF}$ pearls, the luminescence intensity was determined by LUF57 photometer. The determination of thorium was carried out photocolorimetrically with arsenazo III with the separation of impurities by KU-2 cation exchange resin, the sensitivity of the method $-1.0 \cdot 10-8 \mathrm{~g} / \mathrm{g}$. Radium was determined by the emanation method using Alpha-1 instrument, sensitivity 2.0·10-12 g/g.

The absorption strength (or desorption) was evaluated by the content in the extracts obtained by sequential treatment of the sorbent enriched with radionuclides with distilled water, $1 \mathrm{M}$ solutions of ammonium acetate $\left(\mathrm{CH}_{3} \mathrm{COONH}_{4}\right)$ and $1 \mathrm{M}$ hydrochloric acid $(\mathrm{HCl})$.

\subsection{Experiments on purification of domestic and wastewater of industrial enterprises}

We carried out studies on purification of drinking water of the Vychegda river. During our studies we compared effect of various types of filter media: analcime-bearing rocks with a grain size of $-3.0+1.0 \mathrm{~mm}$ and quartz sand, which is currently used at a local water treatment plant. Filtered water samples were taken every 3 hours for 36 hours. The color, turbidity, iron content and permanganate oxidation were determined in the obtained samples according to standard methods. The initial indicators of water were as follows: turbidity $-2.71 \mathrm{mg} / \mathrm{dm}^{3}$, chromacity - 21 degrees, iron (total) $-1.06 \mathrm{mg} / \mathrm{dm}^{3}$, permanganate oxidation $-3.0 \mathrm{mg} / \mathrm{dm}^{3}$.

We conducted experiments on purification of wastewater from a boot factory (Vylgort town). The filter column was filled with an analcime-bearing rocks and contaminated water was passed through it. The following parameters were determined in the filtered water: $\mathrm{pH}$, suspended solids, turbidity, COD, ammonium, oil products, phosphates.

\subsection{Modeling of biogeosorbents for destruction of oil products}

The following organisms were used as oil destructing organisms: Biotrin [25]: Pseudomonas yamanorum VKM B-3033D bacteria [26]; Rhodotorula glutinis yeast, VKM Y-2998D [27]; microalgae Chlorella vulgaris Beijer. f. globosa V. Andr [28]. 
The bacteria biomass was accumulated on MPA medium: per $1000 \mathrm{ml}$ of water - peptone $-20 \mathrm{~g}, \mathrm{NaCl}-3.0 \mathrm{~g}$; $\mathrm{KCl}-1.0$ $\mathrm{g} ; \mathrm{MgSO}_{4} \cdot 5 \mathrm{H}_{2} \mathrm{O}-0.5 \mathrm{~g}$ at a temperature of $15-25^{\circ} \mathrm{C}$ for $3-5$ days under liquid-phase fermentation.

Yeast biomass - on Czapek's medium: per $1000 \mathrm{ml}$ of water - sucrose $20 \mathrm{~g}, \mathrm{NaNO}_{3}-3.0 \mathrm{~g} ; \mathrm{KH}_{2} \mathrm{PO}_{4}$ - $1.0 \mathrm{~g}$; $\mathrm{KCl}$ - $0.5 \mathrm{~g}$; $\mathrm{MgSO}_{4} \cdot 7 \mathrm{H}_{2} \mathrm{O}-0.5 \mathrm{~g}$ at a temperature of $15-25^{\circ} \mathrm{C}$ for $3-5$ days under liquid-phase fermentation.

Microalgae biomass -on Tamiya medium: per $1000 \mathrm{ml}$ of water $-\mathrm{KNO}_{3}-5.0 ; \mathrm{FeSO}_{4} \cdot 7 \mathrm{H}_{2} \mathrm{O}-0.003 \mathrm{~g} ; \mathrm{MgSO}_{4} \cdot 5 \mathrm{H}_{2} \mathrm{O}-2.5$ g; $\mathrm{KH}_{2} \mathrm{PO}_{4}-1.25$ gat a temperature of $15-25{ }^{\circ} \mathrm{C}$ for $3-5$ days under liquid phase fermentation. The resulting suspensions were combined into a biological product "Biotrin".

Biogeosorbents were produced by processing analcimebearing rocks with a particle size of $0.1-0.25 \mathrm{~mm}$ using Biotrin biological product $\left(10^{9}\right.$ cell titer) in the ratio 1 part of the biological product to 6 parts of the sorbent.

Preparation of oil-contaminated water (control). 0.5 $\mathrm{g}$ of oil was added to $100 \mathrm{ml}$ of Czapek's medium without sucrose. It was aerated in a shaker at $180 \mathrm{rpm}$ for 4 days at room temperature and natural light. The water was filtered. The standards for maximum permissible concentration (MPC) of oil products in the waters of fishery water bodies are 0.05 $\mathrm{mg} / \mathrm{dm}^{3}$ [29]. The oil content in the control water sample is 2.4 times higher than MPC.

Experiment conditions. Prepared oil-contaminated water was poured into $250 \mathrm{ml}$ flasks and $1 \mathrm{~g}$ of the initial sorbents (without Biotrin) and biogeosorbents were added. The experiment was carried out for 4 days at room temperature, natural light, aeration on a shaker (180 rpm). The oil content in model water samples, filtered initial sorbents and biogeosorbents was analyzed by fluorimetry by Fluorat- 02 fluid analyzer.

\subsection{Modeling of biogeosorbents for phenol destruction}

As phenol destructors, we used microalgae Chlorella vulgaris Beijer f. globosa V. Andr [28]. The microalgae strain was grown on Tamiya medium in Biostat ${ }^{\oplus}$ A MO UniVessel ${ }^{\oplus}$ Glass BB8822000 2L 230V fermenter for 3-5 days under conditions of liquid-phase fermentation at $350 \mathrm{rpm}$, temperature 25-27 ${ }^{\circ} \mathrm{C}, \mathrm{pH}$ 5.5-6.5, lighting byphytolamp175-250V $50 \mathrm{~Hz}$ until the titer of cells in a suspension of $108 \mathrm{cells} / \mathrm{cm}^{3}$ was reached. Tamiya medium (per $1 \mathrm{dm}^{3}$ of deionized water) of the following composition: $\mathrm{KNO}_{3}-5 \mathrm{r}, \mathrm{KH}_{2} \mathrm{PO}_{4} \times 3 \mathrm{H}_{2} \mathrm{O}-1.25 \mathrm{r}$, $\mathrm{MgSO}_{4} \times 7 \mathrm{H}_{2} \mathrm{O}-2.5 \mathrm{~g}$, trace elements $-1 \mathrm{~cm}^{3}$ each. The trace element solutions are as follows (per $1 \mathrm{dm}^{3}$ of deionized water).

1. Alkaline solution EDTA: EDTA - $50 \mathrm{~g} ; \mathrm{KOH}-31 \mathrm{~g}$.

2. Acidic iron solution: $\mathrm{FeSO}_{4} \times 7 \mathrm{H}_{2} \mathrm{O}-4.98 \mathrm{r}, \mathrm{H}_{2} \mathrm{SO}_{4}-1 \mathrm{~cm}^{3}$.

3. Boric acid solution: $\mathrm{H}_{3} \mathrm{BO}_{3}-11.42 \mathrm{~g}$.

4. The solution of trace elements: $\mathrm{ZnSO}_{4} \times 7 \mathrm{H}_{2} \mathrm{O}-8.82 \mathrm{\Gamma}$; $\mathrm{MnCl}_{2} \times 4 \mathrm{H}_{2} \mathrm{O}-1.44 \Gamma ; \mathrm{MoO}_{3}-0.71 \Gamma ; \mathrm{CuSO}_{4} \times 5 \mathrm{H}_{2} \mathrm{O}-1.57 \Gamma$; $\mathrm{Co}\left(\mathrm{NO}_{3}\right)_{2} \times 6 \mathrm{H}_{2} \mathrm{O}-0.49 \mathrm{~g}$.

Then, a suspension microalgae was sprayed onto a mineral carrier (analcime-bearing rock) and dried at a temperature of 25 ${ }^{\circ} \mathrm{C}$. The ratio of the composition of the biogeosorbent: mineral carrier is $85-90 \%$, the microalgae strain C. vulgaris- 10-15\%.

Microalgae cells were counted by Goryaev-Tom camera [30] under Biomed 3 microscope, binocular: BF, quadruple nose piece, Achromat $4 \mathrm{x} / 10 \mathrm{x} / 40 \mathrm{x} / 100 \mathrm{xMI}$ lenses. The dehydrogenase activity of the aqueous suspension was investigated in accordance with the methodology of the AllRussian Research Institute of Water Resources. The amount of phenols was analyzed by capillary gas chromatography [31].

\section{Results and discussion}

\subsection{Mineralogical-petrographic studies}

The analcime-bearing rocks are represented by Permian aleurolites, argillites and, more rarely, marls with many cavities filled by analcime partially or completely. Mineralogical and petrographic studies determined that oligomictic and polymictic siltstones were characterized by irregular spotted and irregular layered textures, due to the presence of layers and nests composed of material of both psammitic and pelitic dimensions. Clastic material, almost non-rounded and poorly sorted, is represented by quartz, feldspars, muscovite, fragments of effusive rocks. Authigenic minerals include, sericite, chlorite, and pyrite. Claymicaceous and clay-carbonate cement are unevenly ferruginized.
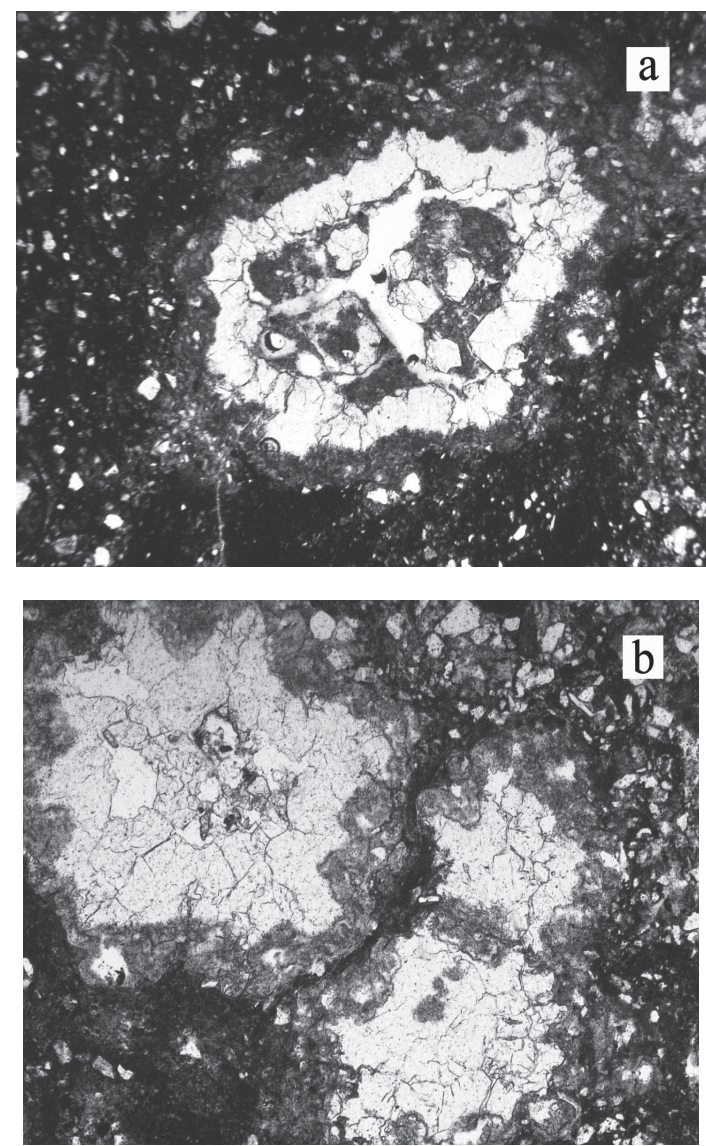

\footnotetext{
1. ábra analcime által bemetszett üreg (a); komplex analcime aggregátumok, amelyek kitöltik az üregeket (b). Átlátszó vékony szakaszok. Magn. x200.

Fig. 1 The cavity incrusted by analcime (a); complex analcime aggregates filling cavities (b). Transparent thin sections. Parallel nicols. Magn. x200.
}

The argillites are also characterized by spotted and layered textures, caused, on the one hand, by uneven ferrugination, and, on the other, by the presence of rock layers consisting of psammite and silt grain. The microstructure of the clay material is scaly and felted. Fragments of quartz, feldspars, carbonates, effusive rocks, flakes of muscovite, chlorite, as well as pyrite and iron hydroxides are noted in the argillites. 


\begin{tabular}{|c|c|c|c|c|c|c|c|c|}
\hline Sample No. & Qtz & Ilt & Chl & MIm & An & Clc & Fsp & Other phases \\
\hline 551 & + & + & + & + & + & - & + & goethite \\
\hline 56403 & + & $+^{*}$ & + & + & + & - & + & goethite \\
\hline $1 / 83$ & + & + & + & + & + & + & + & dolomite, kaolinite \\
\hline 58603 & + & $+^{*}$ & $+?$ & + & + & - & + & - \\
\hline
\end{tabular}

Note: Qtz-quartz, Ilt - illite, Chl-chlorite, Mlm-mixed-layer phase, Glt-glauconite, An - analcime, Clp - clinoptilolite, Clc-calcite, Fsp-feldspar; ${ }^{*}$-modified, hydrated mineral; ? - mineral is unreliable or minor.

1. táblázat Az analcimet hordozó közetek ásványi összetétele röntgendiffrakciós analizissel

Table 1. Mineral composition of analcime-bearing rocks according to X-ray diffraction analysis

\begin{tabular}{|c|c|c|c|c|}
\hline Component & 551 & 56403 & $1 / 83$ & 58603 \\
\hline $\mathrm{SiO}_{2}$ & 54.46 & 60.90 & 35.48 & 63.40 \\
\hline $\mathrm{TiO}_{2}$ & 0.92 & 1.13 & 0.56 & 0.91 \\
\hline $\mathrm{Al}_{2} \mathrm{O}_{3}$ & 17.68 & 15.73 & 11.13 & 14.47 \\
\hline $\mathrm{Fe}_{2} \mathrm{O}_{3 \text { total }}$ & 8.42 & 6.52 & 7.48 & 5.81 \\
\hline MnO & 0.049 & 0.024 & 0.53 & 0.025 \\
\hline $\mathrm{CaO}$ & 0.79 & 0.79 & 14.39 & 2.14 \\
\hline MgO & 1.59 & 1.69 & 4.79 & 1.04 \\
\hline $\mathrm{K}_{2} \mathrm{O}$ & 2.16 & 2.20 & 1.69 & 1.43 \\
\hline $\mathrm{Na}_{2} \mathrm{O}$ & 4.34 & 3.49 & 1.83 & 3.28 \\
\hline $\mathbf{P}_{2} \mathbf{O}_{5}$ & 0.13 & 0.079 & 0.073 & 1.09 \\
\hline LOI & 8.92 & 7.13 & 21.94 & 6.01 \\
\hline Total & 99.46 & 99.68 & 99.89 & 99.61 \\
\hline FeO & 0.31 & 0.62 & 1.23 & $<0.25$ \\
\hline $\mathrm{H}_{2} \mathrm{O}$ & 2.42 & 1.67 & 2.52 & 1.34 \\
\hline $\mathrm{CO}_{2}$ & 0.13 & $<0.1$ & 15.34 & 0.42 \\
\hline
\end{tabular}

2. táblázat Az analcimot hordozó közetek kémiai összetétele, wt. \%

Table 2 Chemical composition of analcime-bearing rocks, wt. \%

\begin{tabular}{lcccccc} 
Sample & $\begin{array}{c}\text { Specific surface area, } \\
\mathbf{m}^{2} / \mathbf{g}\end{array}$ & $\mathrm{C}_{\mathrm{BET}}$ & $\begin{array}{c}\text { Total pore volume, } \\
\mathbf{c m}^{3} / \mathbf{g}\end{array}$ & $\begin{array}{c}\text { Mesopore volume, } \\
\mathbf{\mathbf { c m } ^ { 3 } / \mathbf { g }}\end{array}$ & $\begin{array}{c}\text { Micropore volume, } \\
\mathbf{c m}^{3} / \mathbf{g}\end{array}$ & $\begin{array}{c}\text { Average pore radius, } \\
\mathbf{n m}\end{array}$ \\
\hline $\mathbf{5 5 1}$ & 39.77 & 250.75 & 0.0436 & 0.0317 & 0.017 & 2.19 \\
\hline $\mathbf{5 6 4 0 3}$ & 25.00 & 298.96 & 0.0250 & 0.0169 & 0.010 & 2.00 \\
\hline $\mathbf{1 / 8 3}$ & 38.59 & 287.09 & 0.0347 & 0.0218 & 0.016 & 1.79 \\
\hline $\mathbf{5 8 6 0 3}$ & 23.29 & 370.66 & 0.0205 & 0.0127 & 0.010 & 1.76
\end{tabular}

3. táblázat Az analcimet hordozó kőzetek fajlagos felülete és porozitása

Table 3 Specific surface area and porosity of analcime-bearing rocks

Analcime, the content of which varies from 1 to $30 \%$, is present in the form of various-grained (from fine to coarse-grained) aggregates composed of well-faceted crystals. Analcime aggregates encrust round and oval cavities, and also fill microfractures in the rocks (Fig. 1). Different stages of filling voids are clearly traced from insignificant incrustation to complete substitution.

According to X-ray diffraction analysis, layered silicates are diagnosed by weak reflexes and are probably represented by mixed-layer weakly ordered illite/smectite.

The mineral and chemical compositions of samples of analcime-bearing rocks are presented in Tables 1 and 2 .

\subsection{Sorption parameters}

Textural characteristics are presented in Table 3. The specific surface of the samples is in the range $23.29-39.77 \mathrm{~m}^{2} / \mathrm{g}$.
According to IUPAC classification [32], the nitrogen adsorptiondesorption isotherms of analcime-bearing rocks are related to type IV (a) (Fig. 2a). They are characterized by the presence of a hysteresis loop and are typical of mesoporous sorbents. A sharp rise is observed in the adsorption curve at low pressures, indicating the presence of micropores in the sample $(<2 \mathrm{~nm})$. A rise in the adsorption curve at a relative pressure close to 1 indicates the presence of macropores. The hysteresis loop can be classified as types $\mathrm{H} 3$ and $\mathrm{H} 4$, since clay minerals and zeolites are also present in the sample. The pore size distribution curve is characterized by a narrow pore radius distribution in the range 0.8-4.0 nm with maxima 2.43-2.47 and 1.38-1.54 nm (Fig. 2b).

Promising areas for the use of analcime-bearing rocks are technologies for purification of water resources (drinking, domestic, storm, wastewaters) from heavy metals, organic substances, petroleum products, radionuclides. 

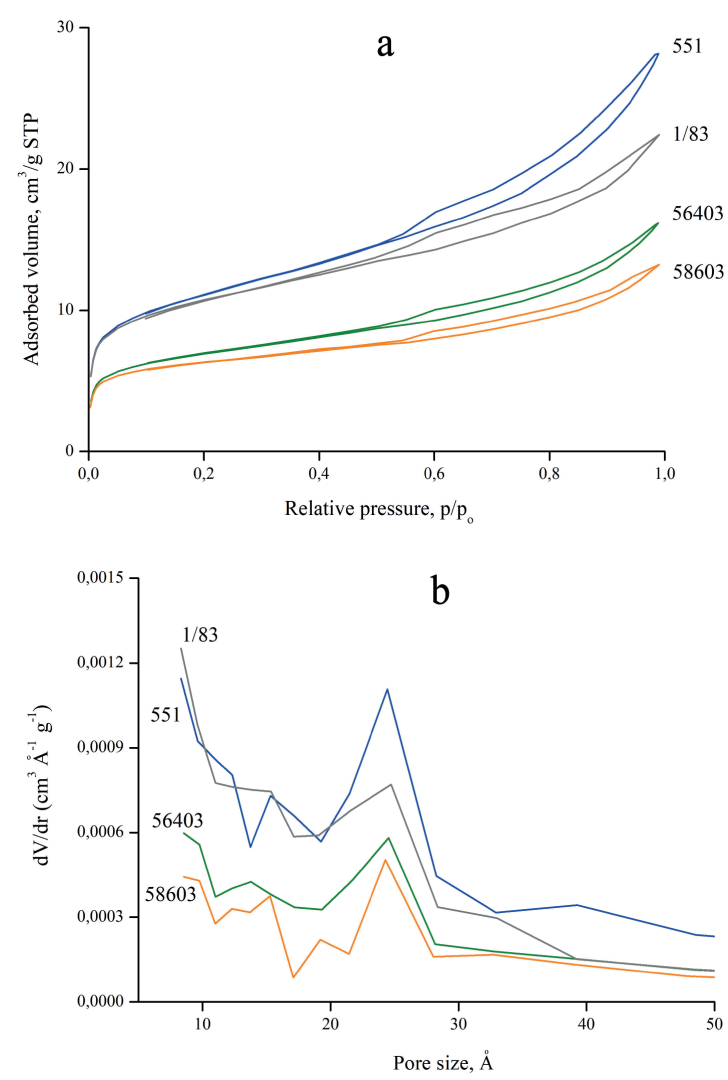

2. ábra Az analcimet hordozó közetek nitrogén-szorpciós-deszorpciós izotermái (a) és pórusméret-eloszlási görbéi (b)

Fig. 2 Nitrogen sorption-desorption isotherms (a) and pore size distribution curves (b) of analcime-bearing rocks

\subsection{Sorption of natural radionuclides}

The results of the study of sorption by analcime-bearing rocks are presented in Table 4. The data obtained show that analcime-bearing rocks completely absorb thorium from the solution. We revealed a high degree of extraction of radium (99.2-99.6\%) and uranium (98.8-99.4\%).

Fig. 3 shows the dynamics of sorption of uranium and radium by analcime-bearing rocks. Uranium sorption proceeds more vigorously, within 30 minutes more than $95 \%$ of uranium is sorbed. More than $97 \%$ of thorium is sorbed within 2.5 hours.

For natural radionuclides, present in natural solutions in ultramicroconcentrations and therefore unable to saturate the sorbent to the limit, an important characteristic is the absorption strength (or desorption) of elements or the compounds formed by them [24, 33].

As mentioned above, desorption was evaluated by the content of radionuclides in the extracts obtained by sequential treatment of the sorbent enriched with radionuclides with distilled water, $1 \mathrm{M}$ solutions of ammonium acetate and hydrochloric acid. When treated with distilled water, watersoluble salts, organic and inorganic compounds pass into the liquid phase. Exposure to ammonium acetate shows the tendency of absorbed radionuclides and their compounds to ion exchange. Stronger forms of radionuclides associated with mobile and stable oxides and soluble organic compounds are extracted with hydrochloric acid. It should be noted that in an acidic environment the destruction of the structure of zeolites and clay minerals is possible, which results in the extraction of radionuclides in solution.

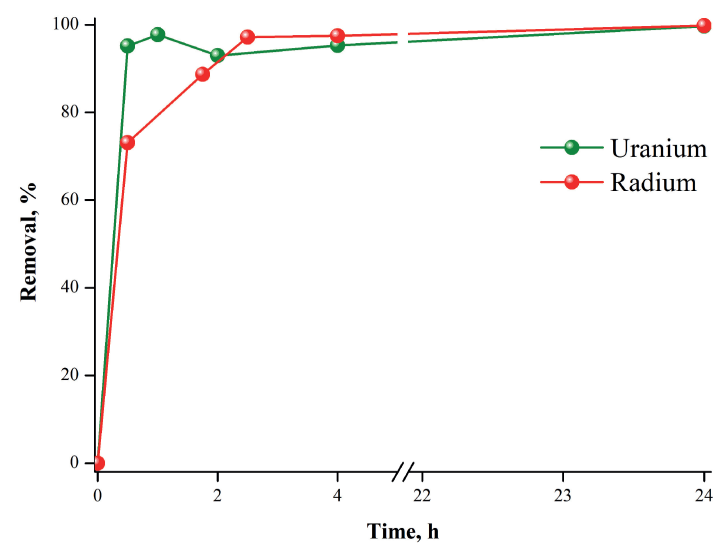

3. ábra Az urán és a rádium extrakciójának dinamikája analcimot hordozó kőzetekkel az oldatból

Fig. 3 Dynamics of the extraction of uranium and radium from the solution with analcime-bearing rocks

The results of the experiments showed (Table 4) that thorium was most firmly retained by the analcime-bearing rocks. We observed a small extraction into the solution upon interaction with water and ammonium acetate. So, when treated with distilled water, $2.0-2.7 \%$ of thorium passes into the solution; when treated with ammonium acetate, $0-0.7 \%$. And only in an acidic environment we observed a significant desorption of thorium - from 47.4 to $60.0 \%$.

As a result of the action of ammonium acetate from the considered radioactive elements, radium is most prone to ion exchange, which results in its significant extraction into the solution from analcime-bearing rocks (47.0-53.2\%). When treated with water, radium is firmly retained by the analcimebearing rocks - less than $0.3 \%$ is desorbed. Acid treatment also supports recovery of radium.

Analcime-bearing rocks firmly retain uranium when treated with water: only $0.1-0.3 \%$ of the radionuclide is recovered, but when exposed to ammonium acetate and acid, 18.1-21.0 and 29.5-34.0\% respectively pass into the solution, respectively.

The combination of high sorption ability with the ability to hold contaminants strongly is an important characteristic of the sorption material from the point of view of its practical use, since it allows avoiding secondary (reverse) contamination of the working environment with radionuclides. Fundamentally, sorbents can be used to trap and retain radionuclides in solutions over a wide range of radionuclide concentrations. It also increases the scope of sorption material - from low concentrated natural waters to highly radioactive liquid waste from nuclear power plants. The data obtained show the advisability of using these sorbents to solve environmental problems, including those associated with the rehabilitation of radiation-contaminated territories.

\subsection{Sorption of pollutants in the treatment of drinking water and wastewater enterprises}

Fig. 4 a-d presents results of drinking water purification from the Vychegda river during filtration through analcimebearing rock and silica sand, which is currently used at a local 


\begin{tabular}{|c|c|c|c|c|}
\hline 551 & 99.6 & 0.01 & 52.33 & 30.93 \\
\hline 56403 & 99.6 & 0.35 & 52.91 & 27.05 \\
\hline $1 / 83$ & 99.5 & 0.24 & 47.03 & 29.39 \\
\hline 58603 & 99.2 & 0.91 & 53.24 & 25.04 \\
\hline \multicolumn{5}{|c|}{ Uranium (initial concentration in solution $0.8 \cdot 10^{-6} \mathrm{~g} / \mathrm{ml}$ ) } \\
\hline 551 & 99.2 & 0.3 & 17.65 & 34.03 \\
\hline 56403 & 99.4 & 0.17 & 20.96 & 33.54 \\
\hline $1 / 83$ & 98.8 & 0.21 & 18.99 & 29.54 \\
\hline 58603 & 98.9 & 0.10 & 18.11 & 30.74 \\
\hline \multicolumn{5}{|c|}{ Thorium (initial concentration in solution $0.5 \cdot 10^{-6} \mathrm{~g} / \mathrm{ml}$ ) } \\
\hline 551 & 100 & 2.33 & 0.00 & 51.33 \\
\hline 56403 & 100 & 2.67 & 0.33 & 60.00 \\
\hline $1 / 83$ & 100 & 2.00 & 0.67 & 53.33 \\
\hline 58603 & 100 & 2.67 & 0.33 & 47.33 \\
\hline
\end{tabular}

4. táblázat A természetes radionuklidok szorpciója analcimet hordozó közetek segítségével Table 4 Sorption of natural radionuclides by analcime-bearing rocks
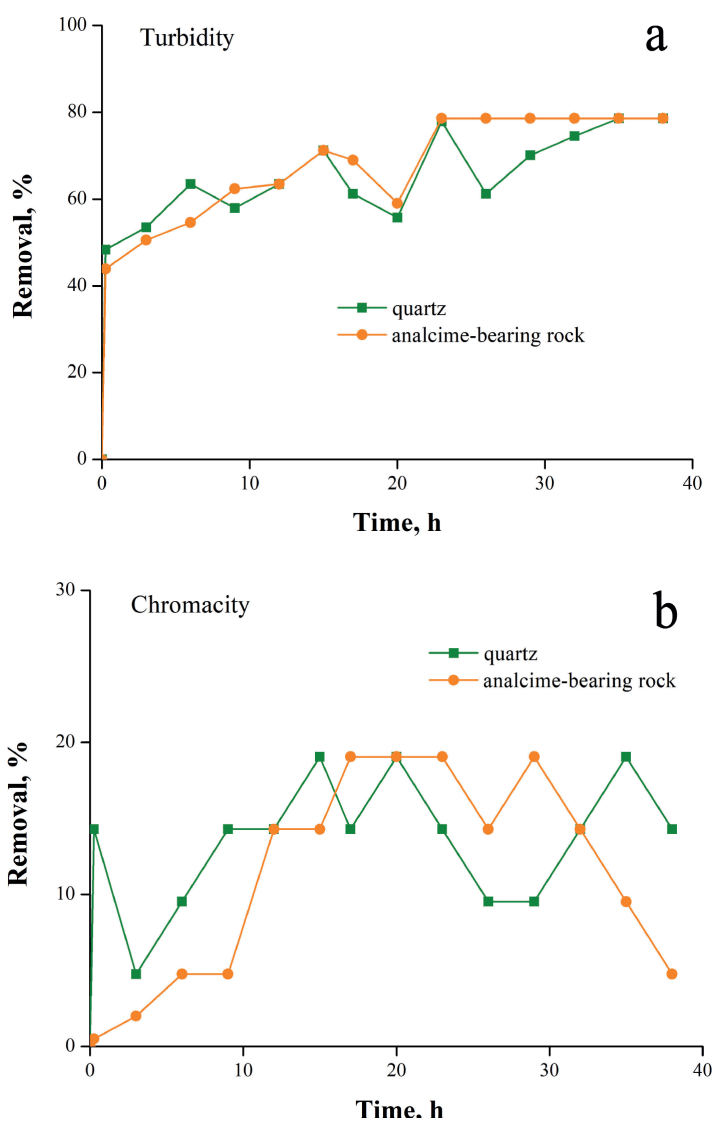
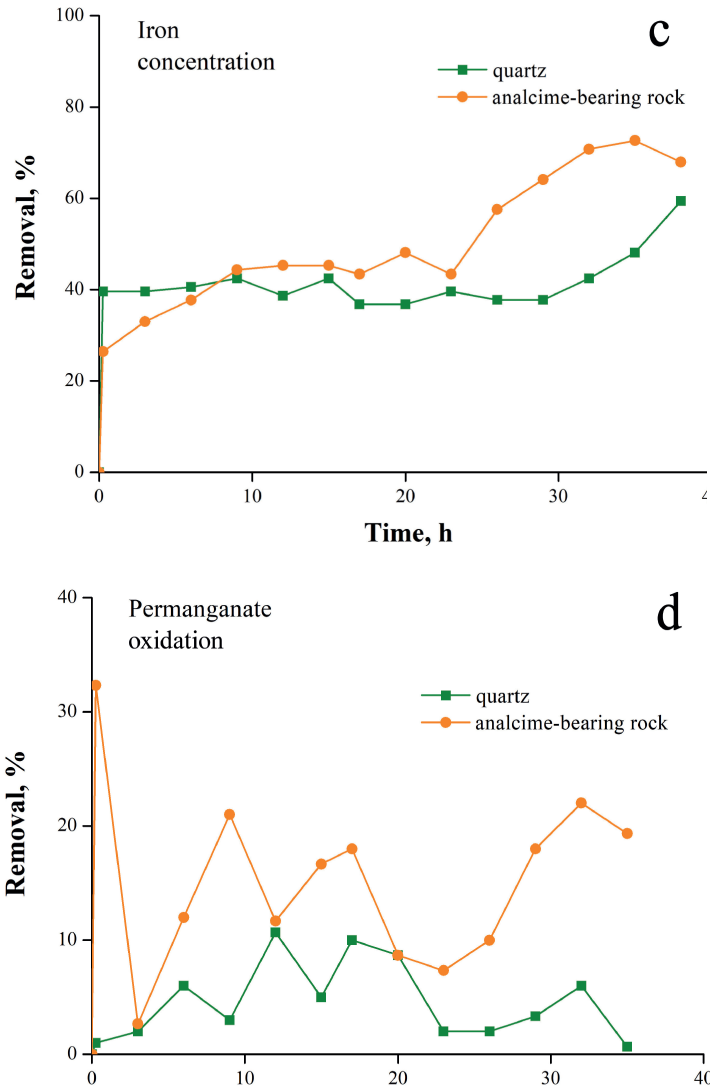

Time. h

4. ábra Zavarosság (a), krómképesség (b), vastartalom (c) és permanganát-oxidálhatóság (d), amikor a vizet szürjük analcimet hordozó kőzet és kvarc homokon

Fig. 4 Turbidity (a), chromacity (b), iron content (c) and permanganate oxidability $(d)$ when filtering water through analcime-bearing rock and quartz sand

water treatment plant. Both types of filter media approximately equally improve the organoleptic indicators of water quality: chromacity and turbidity decrease by 20 and $78 \%$, respectively. However, the analcime-bearing rock significantly reduces the iron content in water and permanganate oxidation: by 32 and $11 \%$, respectively [34, 35].
Table 5 presents results of wastewater treatment from boot factory (Vylgort town). The experiments revealed a significant decrease in the following indicators: suspended solids, turbidity, COD, ammonium, petroleum products, phosphates. Increasing $\mathrm{pH}$ of water from acidic (4.57) to neutral (7.32) was noted [7]. 


\begin{tabular}{|c|c|c|c|c|c|c|c|c|}
\hline & pH & $\begin{array}{l}\text { Suspended solids, } \\
\mathrm{mg} / \mathrm{dm}^{3}\end{array}$ & Turbidity & $\begin{array}{l}\text { COD, } \\
\mathrm{mg} / \mathrm{dm}^{3}\end{array}$ & $\begin{array}{l}\mathrm{N}-\mathrm{NH}_{4}, \\
\mathrm{mg} / \mathrm{dm}^{3}\end{array}$ & $\begin{array}{l}\mathrm{PO}_{4}{ }^{3-} \\
\mathrm{mg} / \mathrm{dm}^{3}\end{array}$ & $\begin{array}{l}\text { Oil products, } \\
\mathrm{mg} / \mathrm{dm}^{3}\end{array}$ & $\begin{array}{l}\text { Anionic surfactants, } \\
\mathrm{mg} / \mathrm{dm}^{3}\end{array}$ \\
\hline Before treatment & 4.57 & 340 & 247 & 210 & 5.0 & 1.3 & 0.31 & 0.07 \\
\hline After treatment & 7.32 & 100 & 3.2 & 61 & 0.25 & 0.46 & 0.049 & 0.06 \\
\hline
\end{tabular}

5. táblázat A szennyvíz mutatói az analcimot hordozó közettel történő kezelés előtt és után

Table 5 Indicators of wastewater before and after treatment by analcime-bearing rock

\begin{tabular}{|c|c|c|c|}
\hline Initial samples & Content of oil products* & Biogeosorbents & Content of oil products* \\
\hline 551 & $\frac{0.04 \pm 0.014}{250 \pm 60}$ & 551-B & $\frac{0.11 \pm 0.04}{57 \pm 23}$ \\
\hline 56403 & $\frac{0.046 \pm 0.016}{130 \pm 50}$ & 56403-В & $\frac{0.061 \pm 0.021}{37 \pm 15}$ \\
\hline $1 / 83$ & $\frac{0.048 \pm 0.017}{250 \pm 60}$ & 1/83-B & $\frac{0.071 \pm 0.025}{220 \pm 90}$ \\
\hline 58603 & $\frac{0.071 \pm 0.025}{250 \pm 60}$ & 58603-B & $\frac{0.064 \pm 0.022}{90 \pm 40}$ \\
\hline
\end{tabular}

Oil-contaminated water (control)

$0.12 \pm 0.041$

${ }^{*}$ Note: in the numerator, the content of oil products in the experimental water, $m g / d m^{3}$, in the denominator - the content of oil products in the initial sorbents and biogeosorbents after the experiment, $\mathrm{mg} / \mathrm{g}$

6. táblázat Az olajtermékek vízben való koncentrációjának változása kezdeti analcimet hordozó kőzetek és biogeoszorbensek jelenlétében Table 6 Change of concentration of oil products in water in the presence of initial analcime-bearing rocks and biogeosorbents

\begin{tabular}{|c|c|c|}
\hline \multirow{2}{*}{ Sample } & \multicolumn{2}{|c|}{ Specific surface area, $\mathrm{m}^{2} / \mathrm{g}$} \\
\hline & Without degassing & With degassing at $25^{\circ} \mathrm{C}, 2$ hours \\
\hline 551 & 13.79 & 16.67 \\
\hline 551B & 13.65 & 8.24 \\
\hline 56403 & 7.05 & 13.30 \\
\hline 56403B & 3.20 & 4.74 \\
\hline $1 / 83$ & 10.07 & 9.34 \\
\hline 1/83B & 10.98 & 8.88 \\
\hline 58603 & 10.40 & 12.85 \\
\hline 58603B & 6.37 & 7.15 \\
\hline
\end{tabular}

7. táblázat A kezdeti analimet tartalmazó hordozó közetek és biogeoszorbensek fajlagos felülete (szemcseméret 0,1-0,25 mm)

Table 7 Specific surface area of initial analcime-bearing rocks and biogeosorbents (grain size 0.1-0.25 mm)

Lanina et al. [36] showed exploitability of using analcimebearing rocks in the technological scheme of treatment of wastewaters from boilers of gas production department (Vuktyl town) as a granular filter load for removing mechanical impurities, organic compounds, nitrates, ammonium nitrogen, $\mathrm{Fe}$ ions with subsequent membrane cleaning. Lanina et al. [37, 38] revealed high absorptive characteristics of these rocks during the treatment of drilling wastewater generated during oil production.

\subsection{Sorption and destruction of oil products by biogeosorents}

For the northeast of the European part of Russia as an oilproducing region, the problems of contamination of territories with oil and oil products during exploration, production, transportation, storage and processing are very relevant. One of the ways to solve the problem is to use biogeosorbents based on zeolite-containing rocks as a carrier for microorganisms-oil destructors.

Table 6 presents results of a change in the concentration of petroleum products in model water in the presence of initial analcime-bearing rocks and biogeosorbents. Samples of the original analcime-bearing rock $(551,56403,1 / 83)$ show adsorption activity against petroleum products. As a result of the introduction of these samples into oil-contaminated water, the pollutant content in water decreases 2.5-3 times over 4 days, below the maximum permissible concentration.

When biogeosorbents (551-B, 56403-B, 1/83-B, 58603-B) are introduced into contaminated water, the efficiency of water purification decreases and does not reach MPC standards, which indicates decreasing sorption properties after immobilization of microorganism cells on mineral carriers. The decrease of the sorption properties of biogeosorbents is probably caused by a decrease in the specific surface area resulted from the adhesionally fixed biomass of microorganisms. This is confirmed by the experimental data on the determination of the specific surface area of the initial analcime-bearing rocks and biogeosorbents (Table 7). In almost all cases, the specific surface area of the initial sorbents is higher than the specific surface of biogeosorbents. When microorganisms are immobilized on analcime-bearing rocks, the specific surface area decreases 1.1-2.8 times.

The analysis of the water part of microcosms after introducing samples of both the original analcime-bearing rocks and biogeosorbents based on them showed that, with significantly high water purification, the differences between the sorbent/ biogeosorbent variants are insignificant, and significant differences were noted in sample 551. Biodegradation of oil products by biogeosorbents for 4 days ranged from 12 to $77 \%[39,40]$. 


\subsection{Sorption and destruction of phenols by biogeosorbents}

We evaluated sorption and destructive properties of initial sorbents, a suspension of microalgae Chlorella vulgaris, and simulated biogeosorbents in relation to phenols (initial concentration $10 \mu \mathrm{g} / \mathrm{dm}^{3}$ ) (Table 8 ). We revealed the advantage of the synergetic complex of the biogeosorbent from its individual components: a decrease in the period of water purification from phenols. Biodegradation of $83 \%$ of phenols in model water occurs in 3 days.

\begin{tabular}{lcc} 
& 3 days & $\mathbf{4 5}$ days \\
C0 & 8.34 & - \\
\hline EC & 7.42 & 3.0 \\
\hline MA & 2.16 & 0.83 \\
\hline A & 1.85 & 0.21 \\
\hline AMA & 1.07 & 0.19
\end{tabular}

Note: CO - zero control, EC - experimental control, MA - microalgae, A - analcimebearing rocks, AMA - analcime-bearing rock with immobilized microalgae

$$
\begin{array}{cl}
\text { 8. táblázat A fenolkoncentráció vízben }(\mu \mathrm{g} / \mathrm{dm} 3) \text { mikroalgákkal, analcimet hordozó } \\
\text { közettel és biogeoszorbenssel való kölcsönhatás után } \\
\text { Table } 8 \begin{array}{l}
\text { Phenol concentration in water }\left(\mu g / \mathrm{dm}^{3}\right) \text { after interaction with microalgae, } \\
\text { analcime-bearing rock and biogeosorbent }
\end{array}
\end{array}
$$

The biogeosorbent was tested for resistance to stress factors: relatively high temperatures, conditions of high salinity and the influence of organic pollutants. For this, samples of the biogeosorbent were thermostated at a temperature of $80{ }^{\circ} \mathrm{C}$, introduced into model phenolic water (concentration $10 \mu \mathrm{g} / \mathrm{dm}^{3}$ ) and sea water (salinity $34 \%$ o).

The mineral carrier provides safety and increases growth of microalgae cells under stressful conditions. Microalgae Chlorella vulgaris, immobilized on analcime-bearing rock, show tolerance to increased salinity and organic pollutants. However, during thermostating of the biogeosorbent, no living microalgae cells were found [41].

\section{Conclusions}

The results obtained show the potential of using analcimebearing rocks in the north-east of the European part of Russia in sorption processes.

We determined a high sorption activity with respect to radioactive elements: degree of absorption of radium, uranium, and thorium was up to $99.6,99.4$, and $100 \%$, respectively. The study of desorption characteristics showed that sorbents had a sufficiently high absorption strength (or low total desorption).

We showed prospects of using these rocks in the treatment of drinking and wastewater of enterprises. It is possible to use them in a sorption-filtering material for purification of household waters in quick filters of water intake structures instead of quartz sand.

We evaluated sorption and destructive properties of initial analcime-bearing rocks and modeled biogeosorbents in relation to oil products. We determined that samples of initial sorbents showed a high adsorption activity in relation to oil products, reducing oil content by 2.5-3 times (to norms or significantly lower than MPC norms).

When immobilizing microorganism cells on the surface of analcime-bearing rocks, a decrease in sorption properties was revealed, but at the same time, microorganisms provided biodegradation of hydrocarbons, which amounted to $77 \%$ in 4 days.

Analcime-bearing rocks provide safety and increases growth of microalgae cells under stressful conditions. Microalgae Chlorella vulgaris, immobilized on analcime-bearing rocks, show tolerance to increased salinity (salinity $34 \%$ ) and phenols (concentration $10 \mu \mathrm{g} / \mathrm{dm}^{3}$ ).

The advantage of the synergetic complex of the biogeosorbent in comparison to individual components is revealed: a decrease in the period of water purification from phenols. Biodegradation of $83 \%$ of phenols in model water occurs in 3 days.

\section{Acknowledgments}

The authors are grateful to Center of Collective Usage "Geonauka» of the Institute of Geology of the FRC Komi Science Center UB RAS and the eco-analytical laboratory of the Institute of Biology of the FRC Komi Science Center UB RAS for their assistance in the analytical works.

This work was partially supported by State Task No. AAAA-A17-117121270025-1 "Development of biocatalytic systems based on enzymes, microorganisms and plant cells, their immobilized forms and associations for processing plant materials, obtaining biologically active substances, biofuels, remediation of contaminated soils and of wastewater treatment" and No. AAAA-A17-117121270037-4 "Scientific basis for effective subsoil use, development and development of the mineral resource base, development and implementation of innovative technologies, geological and economic zoning of the Timan-North Ural region".

\section{References}

[1] Tazić, Z. Z. - Bogdanović, G. D. - Antonijević M. M. (2019): Application of natural zeolites in wastewater treatment - A review. Journal of Mining and Metallurgy A: Mining. Vol. 55, 1, pp. 67-79.

[2] Williams, C. D. (2018): Applications of zeolites to environmental remediation. Chapter in book Urban pollution: Science and Management. First Edition. Edited by Susanne M. Charlesworth and Colin A. Booth. pp. 249-258.

[3] Yona, Z. (2016): Review of the natural, modified and synthetic zeolites for heavy metal removal from wastewater. Environmental Engineering Science. Vol. 33, No. 7.pp. 443-454. https://doi.org/10.1089/ees.2015.0166

[4] Misaelidis, P. (2019): Clay minerals and zeolites for radioactive waste immobilization and containment: a concise overview. Chapter in book Modified Clays and Zeolites nanocomposite materials. pp. 243-274. https://doi.org/10.1016/B978-0-12-814617-0.0004-9

[5] Demirkiran, A. R. - Fullen, M. - Williams, C. (2016): Physicochemical and oil adsorption characteristics of zeolites: clinoptilolites (review). Oxidation Communications. 39, No. 3-II, pp. 2704-2721.

[6] Kalita, B. - Bora, S. S. - Gogoi, B. (2020): Zeolite: a soil conditioner. International Journal of Current Microbiology and Applied Sciences. Vol. 9, No. 1, pp. 1184-1206. https://doi.org/10.20546/ijcmac.2020.901.133

[7] Kotova, O. B. - Harja, M. - Cretescu, I. - Noli, F. - Pelovski, Y. - Shushkov, D. A. (2017): Zeolites in technologies of pollution prevention and remediation of aquatic systems. Vestnik of the Institute of Geology, Komi SC, UB RAS. No. 5. pp. 49-53. https://doi.org/10.19110/2221-1381-2017-5-49-53

[8] Dalang, S. - Mohd Tuah, P (2016): Removal of phenol byzeolite. Transactions on Science and Technology. Vol. 3(1-2), pp. 107-113.

[9] Chaouati, N. - Soualah, A. - Chater, M. (2013): Adsorption of phenol from aqueous solution onto zeolite $\mathrm{Y}$ modified by silylation. Comptes Rendus Chimie. Vol. 16, Iss. 3, pp. 222-228. https://doi.org/10.1016/j.crci.2012.10.010

[10] Coombs, D. S. - Albert, A. - Armbruster, T - et al (1997): Recommended nomenclature for zeolite minerals: report of the Subcommittee on Zeolites of the IMA, Commission on New Minerals and Mineral Names. The Canadian Mineralogist. Vol. 35, pp. 1571-1606. 
[11] Colella, C. - Wise, W. S. (2014): The IZA Handbook of Natural Zeolites: A tool of knowledge on the most important family of porous minerals. Microporous and Mesoporous Materials. Vol. 189, pp. 4-10.

[12] Margeta, K. - Logar, N. Z. - Šiljeg, M. - Farkaš, A. (2013): Natural zeolites in water treatment - how effective is their use. Chapter in book Water Treatment. Pp. 81-112. https://doi.org/10.5772/50738

[13] Chica, A. (2013): Zeolites: promised material for the sustainable production of hydrogen. ISRN Chemical Engineering. Article ID 907425. 19 p. https://doi.org/10.1155/2013/907425

[14] Yusupov, T. S. - Shumskaya, L. G. (2009): A new concept for the production of aluminum and its compounds from non-traditional aluminosilicate raw materials. Phizico-tekhnicheskie Problemy Razrabotki Poleznyh Iskopaemyh (Physicotechnical Problems of Mining). No. 2, pp. 96-100. (In Russian)

[15] Razmakhnin, K. K. - Khatkova, A. N. (2014): Modern technologies of processing and modification of zeolite-bearing rocks of East Transbaikalia. Chita: ZabSU. 310 p. (In Russian)

[16] Khatkova, A. N. - Razmakhnin, K. K. - Emelyanov, V. N. (2013): The possibility of extracting aluminum from zeolite-bearing rocks of East Transbaikalia. Vestnik of IrGTU No. 2, pp. 95-100. (In Russian)

[17] Silaghi, M.-C. - Chizallet, C. - Sauer, J. - Raybaud, P. (2016): Dealumination mechanisms of zeolites and extra-framework aluminum confinement. Journal of Catalysis. 339, pp. 242-255. http://dx.doi.org/10.1016/j.jcat.2016.04.021

[18] Shushkov, D. A. - Kotova, O. B. - Goldin, B. A. (2011): Geomaterials on the basis of analcime-bearing rocks. Geomaterials. No. 1, pp. 33-40. http://dx.doi.org/10.4236/gm.2011

[19] Razmyslov, I. N. - Kotova, O.B. - Silaev, V. I. - Rostovtsev, V. I. - Kiseleva, D. V. -Kondratiev, S. A. (2019): Microphase heterogenization of glandular bauxite as a result of radiation-thermal treatment. FTPRPI. No. 5, pp. 128-140. (In Russian) http://dx.doi.org/10.15372/FTPRPI20190514

[20] Shchipalkina, N. V. - Pekov, I. V. - Koshlyakova, N. N. - Britvin, S. N. Zubkova, N. V. - Varlamov, D. A. - Sidirov, E. G. (2020): Unusual silicate mineralization from fumarolic sublimates of the Tolbachik volcano, Kamchatka, Russia. Part I. Ino-, cyclo-, neso-, phyllosilicates. European Journal of Mineralogy. Vol. 32, pp. 101-119.

[21] Shchipalkina, N. V. - Pekov, I. V. - Koshlyakova, N. N. - Britvin, S. N. - Zubkova, N. V. - Varlamov, D. A. - Sidirov, E. G. (2020): Unusual silicate mineralization from fumarolic sublimates of the Tolbachik volcano, Kamchatka, Russia. Part II. Tectosilicates. European Journal of Mineralogy. Vol. 32, pp. 121-136.

[22] Sitnikov, P. A. - Kuchin, A. V. - Belykh, A. G. - Vaseneva, I. N. - Ryabkov, Yu. I. (2011): Preparation of epoxy composite material containing natural aluminosilicate filler. Polymer Science, Series D. Glues and Sealing Materials. Vol. 4, No. 4, pp. 281-283.

https://doi.org/10.1134/S1995421211040125

[23] Kotova, O. B. - Shushkov, D. A. - Gömze, L. A. - Kurovics, E. - Ignatiev, G. V. - Sitnikov, P. A. - Ryabkov, Yu. I. - Vaseneva, I. N. (2019): Composite materials based on zeolite-montmorillonite rocks and aluminoslicate wastes. Építöanyag - Journal of Silicate Based and Composite Materials. Vol. 71, No 4, pp. 125-130. https://doi.org/10.14382/epitoaniag-jsbcm.2019.22

[24] Rachkova, N. G. - Shuktomova, I. I. (2006): The role of sorbents in the processes of transformation of uranium, radium, and thorium compounds in podzolic soil. St. Petersburg: Nauka.146 p.

[25] Conclusion about toxicological and hygienic assessment of Biotrin consortium of oil-oxidizing microorganisms strains. SIC TBP branch «State Research Center Institute of Immunology» Serpukhov, 09/28/2017. (In Russian)

[26] RU Patent 2615458. The bacterial strain Pseudomonas yamanorum VKM B-3033D for activating the biodegradation of petroleum and petroleum products in water, as well as in oil soils in railway sections / BIOECOBALANCE LLC; Meshkelo, S.M. - Schemelinina, T. N. Anchugova, E. M. - Markarova, M. Yu. - Zheludkova, S. V. Stated 10/08/2016; Publ. 04/04/2017, Bull. No. 10. (In Russian)

[27] RU Patent 2658134. The strain of the yeast Rhodotorula glutinis for the purification of oil-contaminated soils, ponds and wastewater from petroleum hydrocarbons, including for the oxidation of polyaromatic compounds / BIOECOBALANCE LLC; Meshkelo, S. M. - Schemelinina, T. N. - Markarova, M. Yu. - Anchugova, E. M. Stated 07/02/2016; Publ. 06/20/2018, Bull. No. 17.
[28] RU Patent 2703499. Microalgae strain Chlorella vulgaris Beijer. f. Globosa V. Andr. For the purification of natural reservoirs and wastewater of industrial enterprises / Schemelinina, T. N. - Anchugova, E. M. - Gogonin, A. V. Tarabukin, D. V. -Shapenkov, D. M.. Published: 10/17/2019, Bull. No. 29.

[29] On approval of water quality standards for water bodies of fishery importance, including standards for maximum permissible concentrations of harmful substances in the waters of water bodies of fishery value: Order of the Ministry of Agriculture of the Russian Federation of December 13 2016. No. 552. URL: http://docs.chdt.ru

[30] Benjumovich, M. S. (2001): The application of Poisson units to the determination of median lethal cell culture dose. Toxicology in Vitro. Vol. 15, Iss. 6, pp. 671-675. https://doi.org/10.1016/S0887-2333(01)00086-8

[31] The method of measuring the mass concentration of phenol by capillary gas chromatography. No. 88-17641-006-2013 (FR.1.31.2013.15054). 2013 Edition (In Russian)

[32] Thommes, M. - Kaneko, K. - Neimark, A. V. - Olivier, J. P. - RodriguezReinoso, F. - Rouquerol, J. - Sing, K. S. W. (2015): Physisorption of gases, with special reference to the evaluation of surface area and pore size distribution (IUPAC Technical Report). Pure and Applied Chemistry. Vol. 87, Iss. 9-10. pp. 1051-1069. https://doi.org/10.1515/pac-2014-1117

[33] Shushkov, D. - Kotova, O. - Shuktomova, I. (2013): Removal of radionuclides by analcime-bearing rocks. J. Material Science and Engineering. Vol. 47, pp. 198-202.

http://doi.org/10.1088/1757-899X/47/1/012041

[34] RU Patent 2296718. The method of water purification / Shushkov, D. A. Kotova, O. B. - Palshin, I. P. Stated July 7, 2005. Published. 04/10/2007. (In Russian)

[35] Shushkov, D. A. - Kotova, O. B. - Kapitanov, V. M. - Ignatiev, A. N (2006): Analcime-bearing rocks of Timan as a promising type of minerals. Syktyvkar. 40 p. (Scientific recommendations - to the national economy / Komi Scientific Center, Ural Branch of the Russian Academy of Sciences; issue 123). (In Russian)

[36] Lanina, T. D. - Varfolomeev, B. G. (2007): The use of natural zeolite for post-treatment of wastewater from boiler houses of the Vuktylsky gas production department // Construction of oil and gas wells on land and at sea. No 8, pp. 38-40. (In Russian)

[37] Lanina, T. D. (2009): The use of natural sorbents for drilling wastewater treatment. Construction of oil and gas wells on land and at sea. No 9, pp. 55-56. (In Russian)

[38] Lanina, T. D. - Nosov, G. A. - Donin, S. N. (2017): The use of natural sorbents for wastewater treatment of industrial enterprises. Petroleum Engineer. No. 3, pp. 43-47. (In Russian)

[39] Schemelinina, T. N. - Kotova, O. B. - Harja, M. - Anchugova, E. M. Pelovsky, I. - Cretescu I. (2017): New trends in the mechanisms for increasing the productivity of materials based on minerals. Vestnik of the Institute of Geology, Komi SC, UB RAS. No. 6, pp. 40-42. http://doi.org/10.19110/2221-1381-2017-6-40-42

[40] Shchemelinina, T. N. - Gömze, L. A. - Kotova, O. B. - Ibrahim, J. E. F. M. - Shushkov, D. A. - Harja, M. - Ignatiev, G. V. - Anchugova, E. M. (2019): Clay- and zeolite-based biogeosorbents: modeling and properties. Építöanyag - Journal of Silicate Based and Composite Materials. Vol. 71, No. 4, pp. 131-137. https://doi.org/10.14382/epitoanyag-jsbcm.2019.23

[41] Shchemelinina, T. N. - Anchugova, E. M. - Kotova, O. B. - Sun, S. - Shushkov, D. A. - Gogonin, A. V. - Likhanova, N. V. - Zueva, O. M. - Korchagina, Yu. S. (2020): Why mineral carriers are necessary for microalgae. Vestnik of Geosciences. No 2, pp. 24-28. http://doi.org/10.19110/geov.2020.2.4

Ref.: Shushkov, Dmitry A. - Kotova, Olga B. - Ibrahim, Jamal-Eldin F. M. - Harja, Maria - Gömze, László A. - Shchemelinina, Tatyana N. - Ignatiev, Grigoriy V.: Analcime-bearing rocks as advanced sorbents

Építőanyag - Journal of Silicate Based and Composite Materials, Vol. 72, No. 5 (2020), 156-164. p. https://doi.org/10.14382/epitoanyag-jsbcm.2020.26 